\title{
The Effect of Cigarette Smoke in Bleomicyn Induced Pulmonary Fibrosis in the Rat Model
}

\author{
Emin MADEN ${ }^{1}$, Hatice TOY ${ }^{2}$, Turgut TEKE ${ }^{1}$, Celalettin KORKMAZ ${ }^{1}$, Halil KIYICI ${ }^{3}$, \\ Oktay IMECIK ${ }^{1}$, Mehmet GOK ${ }^{1}$, Kurşat UZUN ${ }^{1}$ \\ ${ }^{1}$ Selcuk University, Meram Medical Faculty, Department of Pulmonary Medicine, Meram, Konya \\ ${ }^{2}$ Selcuk University, Meram Medical Faculty, Department of Pathology, Meram, Konya \\ ${ }^{3}$ Baskent University, Department or Pathology, Konya, TURKEY
}

\begin{abstract}
The role of cigarette smoking in the development and outcome of pulmonary fibrosis is uncertain. In this study, we aimed to assess the effect of route of bleomycin exposure in the development of pulmonary fibrosis and the effects of cigarette smoke on bleomycin-induced lung fibrosis. We studied five groups of rats; 1-control group, 2-intratracheal bleomycin (IT), 3- intratracheal bleomycin plus cigarette smoke for 4 wk (IT-S), 4- inhaled bleomycin (IN), 5- inhaled bleomycin plus cigarette smoke for 4 wk (IN-S). According to Aschoft's criteria, fibrosis score was higher in IT and IT-S compared to control, IN and IN$\mathrm{S}$ groups. There was no significant difference between IT and IT-S groups. Histopathological evaluation of the lungs of rats revealed that neutrophils, macrophages, plasma cells and lymphocytes in alveolar interstitial space were significantly higher in IT and IT-S compared to IN and IN-S ( $p<0.001$ ). IT and IT-S showed a severe collagen, laminin, elastin, fibronectin and proteoglican levels in alveolar, vascular, airway and interstitial space. IN and IN-S showed mild inflammation in lung. There were alveolitis, edema, peribronchial fibrosis, fibroblast proliferation and emphysematous lesions in all groups except for the control group. In this study, we showed that in the development of pulmonary fibrosis in rats, intratracheal administration of bleomycin is more effective than bleomycin inhalation and smoking has no additional effect on development of fibrosis.
\end{abstract}

Keywords: Bleomycin, Pulmonary fibrosis, Cigarette smoking

\section{ÖZET}

\section{Sıçan Modelinde Bleomisine Bağlı Pulmoner Fibroziste Sigara Dumanının Etkisi}

Sigaranın pulmoner fibrozis gelişimindeki ve sonuçlarına etkisi net değildir. Bu çalışmada bleomisin uygulama yolunun pulmoner fibrosis gelişimine ve sigaranın bleomisine bağıı pulmoner fibrosis gelişimi üzerine etkisini değerlendirmeyi amaçladık. Beş grup fare ile çalıştık; 1-kontrol grubu, 2- intratrakeal bleomisin (IT), 3- intratrakeal bleomisin ve 4 hafta süreyle sigara dumanı (IT-S), 4- inhale bleomisin(IN), 5- 4 hafta süreyle inhale bleomisinle birlikte sigara dumanı (IN-S). Aschoft kriterlerine göre fibrosis skoru IT ve IT-S gruplarında kontrol, IN ve IN-S gruplarılya karşılaştııılı̆ğında daha yüksek bulundu. IT ve IT-S grupları arasında belirgin fark yoktu. Farelerin akciğerlerinin histopatolojik incelemesinde alveol ve interstisyel boşluktaki nötrofil, makrofaj, plazma hücreleri ve lenfositler IN ve IN-S grubuna kıyasla IT ve IT-S grubunda belirgin olarak daha yüksekti $(p<0.001)$. IT ve IT-S gruplarında alveolar, vasküler, havayolu ve interstisyel boşlukta yoğun kollajen, laminin, elastin, fibronektin ve proteoglikan düzeyleri izlendi. IN ve IN-S gruplarında akciğerde hafif inflamasyon izlendi. Kontrol grubu dışında tüm gruplarda alveolit, ödem, peribronşial fibrozis, fibroblast çoğalması ve amfizematöz lezyonlar mevcuttu. Bu çalsşmada farelerde pulmoner fibrozis oluşumunda intratrakeal bleomisin uygulamanın inhale bleomisin inhalasyonundan daha etkili olduğu ve sigaranın pulmoner fibrozis gelişiminde ek katkısı bulunmadığını tespit ettik.

Anahtar Kelimeler: Bleomisin, Pulmoner fibrozis, Sigara 


\section{INTRODUCTION}

Bleomycin is an effective agent in the control of a number of human cancers, including squamous cell carcinomas, lymphomas and testicular tumors. It does not have major effects on the bone marrow $^{1}$ or on immunocompetence in animals or humans. ${ }^{2} \mathrm{Ho}-$ wever, the application of bleomycin is sometimes associated with fatal side effects. Due to the lack of the bleomycin-inactivating enzyme, bleomycin hydrolase, in the lungs and the skin $^{3}$ bleomycin-induced toxicity occurs predominantly in these organs. It has a dose-dependent pulmonary toxicity that limits its clinical use. ${ }^{4}$ Intratracheal bleomycin administration in rats and other animal species causes rapid development of pulmonary fibrosis characterized by increased lung collagen synthesis and deposition. ${ }^{5,6,7}$ This toxic effect of the drug has been utilized advantageously in a number of experimental approaches to pulmonary fibrosis in animal models. Several studies have reported that in the early stages of lung damage induced by bleomycin, the lesions are associated with biochemical and functional changes that resemble to those of human pulmonary fibrosis, namely, inflammatory cell infiltration, increased collagen content, and reduced lung volumes and compliance..$^{8-9}$ Development of pulmonary fibrosis after intratracheal administration was demonstrated several times also effect of intravenous administration was evaluated. However, the effect of exposure to bleomycin via inhalation route is not known. During preparation of this drug before administration to the patients, the nurses or the health care personal who prepares it may expose to bleomycin via inhalation route if they do not take the needed precaution. We do not know if this exposure has any undesired effect to these personal. So, we aimed to evaluate the effect of inhaled bleomycin exposure on the lungs of the rats.

Cigarette smoke is a complex mixture of more than 4000 compounds and causes a variety of pulmonary and systemic effects in humans. ${ }^{10,11}$ Chronic smoke exposure causes airway and lung parenchymal inflammation, which is characterized by increased numbers of macrophages, lymphocytes, neutrophils, and/or eosinophils. Several kinds of proteases such as neutrophil elastase, macrophage elastase, matrix metalloproteinases, and cathepsins released from the inflammatory cells may contribute to alveolar destruction and result in pulmonary emphyse- ma in chronic cigarette smokers. ${ }^{10}$ In addition, reactive oxygen species produced by cigarette smoke or inflammatory cells, including activated lung macrophages and infiltrating neutrophils, may contribute to emphysematous changes, in that massive and continuous oxidative stress may overwhelm the antioxidant capacity of lung tissue, thereby causing damage. Smoking has also been implicated in development of interstitial lung disease. However, the role of tobacco smoking in the development and outcome of pulmonary fibrosis is uncertain and controversial. We aimed to evaluate the effect of smoking on the lungs of the rats by administration via inhalation route. Because we did not wanted to kill too much rats and thought that we could evaluate its effect by administration to the rats in addition to bleomycin as we also have groups that exposed only bleomycin by comparing their effect in these group we did not constitute a group that included only rats which exposed to smoking solely.

The aim of this study was to evaluate the effect of the route of bleomycin administration on development of pulmonary fibrosis and examine the effect of cigarette smoking on development of pulmonary fibrosis.

\section{MATERIAL AND METHODS}

The study was performed in adult male SpragueDawley rats (pretreatment body weight, 315 to 375 g) after approval of Institutional Review Board (IRB) (Approval number is 2004-44). To investigate the effects of cigarette smoke on bleomycin-induced lung fibrosis, we studied five groups of rats ( $n=10$ for each group). The bleomycin was given to the rats through intratracheal route or by inhalation as described in previous studies. ${ }^{12,13}$ In the control group (Group 1), ten rats were subjected to saline inhalation. In Group 2, (intratracheal bleomycin group, IT), ten rats received a single dose of bleomycin intratracheally (Nippon Kayaku Co., Ud. Tokyo, Japan) $0.5 \mathrm{U} / 100 \mathrm{~g}$ body weight in $0.3 \mathrm{ml}$ $0.15 \mathrm{M}$ sterile $\mathrm{NaCl}$. Bleomycin solution was prepared immediately before administration and was administered as a single dose directly into the trachea under light anesthesia with sodium pentobarbital $(50 \mathrm{mg} / \mathrm{kg}$ body weight) intraperitoneally. The rats in group 3 were treated same as Group 2 and were exposed to tobacco smoke for 4 weeks (IT-S); 
Table 1. The median (interquartile range expressed as a first - third quartile) of degree of fibrosis score and differential cell counts in alveolar and interstitial tissue of rats

\begin{tabular}{|c|c|c|c|c|c|c|}
\hline & Control & IT & IT-S & INH & INH-S & p \\
\hline \multirow[t]{2}{*}{ Collagen } & 0.0 & 1.0 & 2.0 & 1.0 & 1.0 & \\
\hline & $(0.0-0.25)$ & $(1.0-3.0)$ & $(2.0-2.25)$ & $(0.75-1.0)$ & $(1.0-1.0)$ & 0.001 \\
\hline \multirow[t]{2}{*}{ Diffuse alveolar hemorrhage } & 0.0 & 1.0 & 0.0 & 0.0 & 0.0 & 0.0 \\
\hline & $(0.0-0.0)$ & (0.0-3.0) & (0.0-3.0) & $(0.0-0.0)$ & $(0.0-0.0)$ & 0.002 \\
\hline \multirow[t]{2}{*}{ Fibroblasts } & 0.0 & 2.0 & 2.5 & 1.0 & 1.0 & \\
\hline & $(0.0-0.0)$ & $(1.75-3.0)$ & $(2.0-3.0)$ & $(0.75-1.0)$ & $(1.0-1.0)$ & 0.001 \\
\hline \multirow[t]{2}{*}{ Hyaline membranes } & 0.0 & 0.5 & 0.0 & 0.0 & 0.0 & \\
\hline & $(0.0-0.0)$ & $(0.0-2.25)$ & $(0.0-0.0)$ & $(0.0-0.0)$ & $(0.0-0.0)$ & 0.001 \\
\hline
\end{tabular}

inhalation of cigarette smoke was performed two times a day in a plastic cage $(40 \mathrm{~cm} \times 26 \mathrm{~cm} \times 16$ $\mathrm{cm}$ ). In group 4 (inhaled bleomycin, IN); the rats were placed in a plastic box $(40 \mathrm{~cm} \times 26 \mathrm{~cm} \times 16$ $\mathrm{cm}$ ) attached to the jet nebulizer (Respironics, West Sussex, UK) for 15 min for nebulization of bleomycin and the same procedure was repeated every day for 4 weeks. Rats in group 5 were treated same as group 4 and were exposed to tobacco smoke for 4 weeks (IN-S) as described above.

Following exanguinations of the rats, each lung tissue was fixed in a buffered $10 \%$ formalin solution for $24 \mathrm{hr}$ and embedded in paraffin. Longitudinal sections of the lungs were stained with hematoxylin and eosin (HE) and were examined for pulmonary fibrosis. Each successive field was individually assessed for the severity of interstitial fibrosis using the semiquantitative grading system described by Ashcroft et al. ${ }^{14}$ The entire lung section was reviewed at a magnification of $\mathrm{x} 100$. For each of the 30-35 microscopic fields, a score ranging from 0 (normal) to 8 (total fibrosis) was assigned. Criteria for grading pulmonary fibrosis were as follows: Grade $0=$ normal lung; Grade $1=$ minimal fibrous thickening of alveolar or bronchiolar walls; Grade $3=$ moderate thickening of the walls without obvious damage to the lung architecture; Grade 5= increased fibrosis with definite damage to the lung structure and the formation of fibrous bands or small fibrous masses; Grade 7= severe distortion of the lung structure and large fibrous areas; Grade $8=$ total fibrous obliteration of the field. If there was any difficulty in deciding between two odd-numbered categories, the field was given the intervening even-numbered grade. The pulmonary fibrosis score was expressed as a mean grade of fibrosis for each sample.

Cell counts were expressed as the number per high power field (HPF). Inflammatory infiltrates were further characterized according to cell type on a morphologic basis. Inflammatory changes were expressed as scores of different cell types (neutrophil, macrophage, plasma cells, lymphocytes), this semiquantitative scale was from $1+$ to $3+(1+=$ mild, $2+=$ moderate, $3+=$ marked) for each cell type. The collagen, fibroblasts and hyaline membrane contents and presence of diffuse alveolar hemorrhage in alveolar and interstitial tissue of rats were also scored from $1+$ to $3+$ defined as above.

Statistical Analysis: A nonparametric analysis of variance (Kruskal-Wallis method) was used to determine any significant difference among the five groups. Multiple comparisons were performed by using Mann-Whitney U test with Bonferroni's correction. Data are expressed as median (interquartile range expressed as a first - third quartile). All analyses were performed using the SPSS statistical software package and probability value of $<0.05$ were considered as statistically significant. 


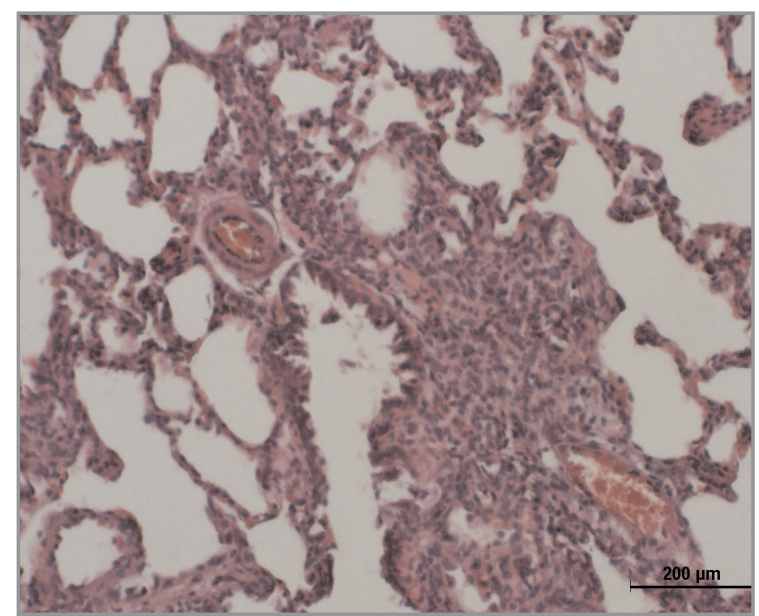

Figure 1. Histopathologic view of the lung of the rats exposed to intratracheal bleomycin with pulmonary fibrosis

\section{RESULTS}

According to Aschoft's criteria, fibrosis score was higher in IT, IT-S, IN and IN-S than control group (Table 1). There was significant difference between the routes of administration of bleomycin, intratracheally vs inhalation. There was no significant difference between IT and IT-S, and IN and IN-S with respect to fibrosis score $(\mathrm{p}=0.68$ and $\mathrm{p}=0.08$, respectively). Fibrosis score was significantly higher in IT than IN $(p<0.001)$. However, there was no difference between IT and IN-S $(\mathrm{p}=0.052)$. Histopathologic evaluation of the lungs revealed that number of neutrophils, macrophages, plasma cells and lymphocytes in alveolar and interstitial space were significantly higher in IT and IT-S compared to IN and IN-S $(\mathrm{p}<0.001)$. A figure demonstrating histopathologic view of the lungs of rats with fibrosis was shown in Figure 1. The mean of degree of collagen, fibroblasts and hyaline membrane contents and presence of diffuse alveolar hemorrhage in alveolar and interstitial tissue of rats was shown in Table 2.

IT and IT-S showed a severe collagen, laminin, elastin, fibronectin and proteoglican levels in alveolar, vascular, airway and interstitial space. However, IN and IN-S caused mild inflammation in lung. There were alveolitis, edema, peribronchial fibrosis, fibroblast proliferation and emphysematous lesions in all groups except for the control group.

\section{DISCUSSION}

Lindenschmidt et al. ${ }^{15}$ investigated the effect of intravenous administration and intratracheal administration of bleomycin on development of pulmonary fibrosis and found that differences existed in the lung reactions in response to these two routes of ad-

Table 2. The median (interquartile range expressed as a first - third quartile) of degree of collagen, fibroblasts and hyaline membrane contents and presence of diffuse alveolar hemorrhage in alveolar and interstitial tissue of rats.

\begin{tabular}{|c|c|c|c|c|c|c|}
\hline & Control & IT & IT-S & INH & INH-S & $\mathbf{p}$ \\
\hline Fibrosis score & 1.0 & 7.0 & 7.0 & 3.5 & 4.5 & \\
\hline (Aschoft's criteria) & $(0.0-1.0)$ & $(4.75-7.0)$ & $(6.0-7.0)$ & $(3.0-4.25)$ & $(3.75-5.5)$ & 0.001 \\
\hline \multirow[t]{2}{*}{ Neutrophils } & 1.0 & 2.5 & 3.0 & 1.5 & 1.0 & \\
\hline & $(1.0-2.0)$ & $(1.0-3.0)$ & $(2.75-3.0)$ & $(0.75-2.0)$ & $(1.0-1.0)$ & 0.002 \\
\hline \multirow[t]{2}{*}{ Macrophage } & 1.0 & 3.0 & 3.0 & 0.0 & 0.0 & \\
\hline & $(1.0-2.0)$ & (2.0-3.0) & (3.0-3.0) & $(0.0-0.0)$ & $(0.0-0.0)$ & 0.001 \\
\hline \multirow[t]{2}{*}{ Plasma cells } & 1.0 & 2.5 & 3.0 & 1.0 & 2.0 & \\
\hline & $(1.0-2.0)$ & $(2.0-3.0)$ & $(2.0-3.0)$ & $(0.75-1.0)$ & $(1.75-2.0)$ & 0.001 \\
\hline \multirow[t]{2}{*}{ Lymphocytes } & 1.0 & 2.0 & 3.0 & 1.0 & 2.0 & \\
\hline & $(1.0-1.0)$ & $(2.0-2.25)$ & (2.0-3.09 & $(0.75-1.0)$ & $(1.75-2.0)$ & 0.001 \\
\hline
\end{tabular}


ministration, but these differences reflected nonspecific inflammatory response and magnitude of initial injury. They concluded that the response to bleomycin administered intratracheally is basically similar to the changes produced by intravenous injection of the drug. However, to our knowledge there is no study evaluating the effect of inhaled bleomycin on lung. In our study, fibrosis score was significantly higher in all rats exposed to bleomycin when compared to control group; but the fibrosis developed after inhalation of bleomycin was lower than the intratracheal administration of this drug. This result showed that bleomycin administration through inhalation route has no significant effect on development of pulmonary fibrosis. It is known that bleomycin has a dose-dependent pulmonary toxicity. ${ }^{4}$ The lower fibrosis score in our study after inhaled bleomycin administration might be due to dose of bleomycin the rats were exposed, because the dose of bleomycin received by the rats in this way is probably lower than the dose given intratracheally. The dose could be adjusted when the bleomycin is given intravenously, intratracheally or subcutaneously, however it is not possible to measure the total dose received by the rats when it is given through inhalation route. Therefore, it could be speculated that as it was shown in previous studies the effect of bleomycin in development of fibrosis is dose dependent. It is reported that collagen content is increased in lungs after bleomycin exposure. Clark et al reported accumulation of collagen in the lung following an increased rate of collagen synthesis. ${ }^{7}$ In our study, we demonstrated increased collagen levels in lung tissues of the rats in IT and IT-S groups. Also increased number of macrophage, lymphocytes and fibroblasts was shown after administration of bleomycin in animal studies. Chandler et al demonstrated an increase in the number of macrophage, lymphocytes, eosinophils and fibroblast at the fourth week of their study. ${ }^{16}$ This was similar to our study as we also demonstrated increased number of macrophages, plasma cells, fibroblasts and lymphocytes in all groups exposed to bleomycin.

The role of tobacco smoking in the development and outcome of pulmonary fibrosis is uncertain and also controversial. The results of our study revealed no significant difference in fibrosis score between none smoke-exposed group and smoke-exposed group. As in our study, there are studies reporting no effect of smoking on development of pulmonary fibrosis and studies reporting inhibitory or positive effect of cigarette smoke on development of fibrosis. Parvinen et al. ${ }^{17}$ investigated the factors affecting the pulmonary toxicity of bleomycin and found that advanced age, high total dose of bleomycin, and intravenous bolus injections of the drug seemed to be major factors responsible for the development of lung fibrosis whereas smoking had no obvious effect. An earlier report by Osanai et al..$^{12}$ evaluating the effect of cigarette smoke on the development of bleomycin (BLM)-induced pulmonary fibrosis in hamsters found that tobacco smoke reduced the fibrotic response to bleomycin, however caused derangement of alveolar architecture. In addition, a number of clinical and experimental studies suggest that cigarette smoking reduces the frequency of radiation- induced pneumonitis. Cigarette smoke may play a critical role in the development and deterioration of pulmonary emphysema by suppressing the growth of lung fibroblasts..$^{18}$ Carvenali et al. ${ }^{19}$ reported that cigarette smoke-induced inhibition of fibroblast proliferation and migration may impair lung repair following lung injury and may thus contribute to the development of pulmonary emphysema. We detected emphysematous changes in pathologic evaluation of rats in all groups except for the control group. On the other hand, there are also studies showing that smoking causes interstitial pulmonary disease. In case-control studies, cigarette smoking has been reported as a potential risk factor for the development of IPF in ever-smokers. ${ }^{20,21,22}$ Results from the study of Lower et al supported the premise that bleomycin pulmonary toxicity may result from the generation of reactive oxygen metabolites and that cigarette smoking may predispose to bleomycin pulmonary toxicity. ${ }^{23}$

The main limitations of our study were inabilities to measure the dose of the bleomycin received by the rats in inhalation groups, however as we put all the rats in the same size of a box and exposed to inhaled bleomycin at a same time of period we thought that all rats exposed to same dose of bleomycin. Another limitation was not to evaluate the inflammatory and fibrotic course in different periods of the study due to low number of rats in study groups. 
In conclusions, we showed that development of pulmonary fibrosis was more dominant in the lungs of rats that were exposed to intratracheal bleomycin and inhalation route resulted in less pulmonary fibrosis, most probably due to lower exposure dose. Smoking had no additional effect on development of bleomycin induced fibrosis.

This article is original and there is no conflict of interest related to this research.

\section{REFERENCES}

1. Boggs SS, Sartiano GR, Demezza A. Minimal bone marrow damage in mice given bleomycin. Cancer Res 34: 1938-1942, 1974.

2. Dlugi AM, Robie KM, Mitchell MS. Failure of bleomycin to affect humoral or cell mediated immunity in the mouse. Cancer Res 34: 2504-2507, 1974.

3. Ohnuma T, Holland JF, Masuda H, et al. Microbiological assay of bleomycin: inactivation, tissue distribution, and clearance. Cancer 33:1230-1238, 1974.

4. Cooper JA, White D, Matthay R. Drug-induced pulmonary disease. Am Rev Respir Dis 133: 321-340, 1986.

5. Snider GL, Hayes JA, Korthy AL. Chronic interstitial pulmonary fibrosis produced in hamsters by endotracheal bleomycin: pathology and stereology. Am Rev Respir Dis 117: 1099-1108, 1978.

6. Starcher BC, Kuhn C, Overton JE. Increased elastin and collagen content in the lungs of hamsters receiving an intratracheal injection of bleomycin. Am. Rev. Respir. Dis 117: 299-305, 1978.

7. Clark JG, Overton JE, Marino BA, et al. Collagen biosynthesis in bleomycin induced pulmonary fibrosis in hamsters. J Clin Med 96: 943-953, 1980.

8. Snider GL, Celli BR, Goldstein RH, et al. Chronic interstitial pulmonary fibrosis produced in hamsters by endotracheal bleomycin. Am Rev Respir Dis 117: 289297, 1978.

9. Zia S, Hyde DM, Giri SN. Development of a bleomycin hamster model of subchronic lung fibrosis. Pathology 24: 155-163, 1992.

10. Cigarette smoking and health. American Thoracic Society. Am J Respir Crit Care Med 153: 861-865, 1996.

11. Murin S, Hilbert J, Reilly SJ. Cigarette smoking and the lung. Clin Rev All Immunol 15: 307-336, 1997.

12. Osanai K, Takahashi K, Suwabe A, et al. The effect of cigarette smoke on bleomycin-induced pulmonary fibrosis in hamsters. Am Rev Respir Dis 138:1276-1281, 1988.

13. Jang AS, Lee JU, Choi IS, et al. Expression of nitric oxide synthase, aquaporin 1 and aquaporin 5 in rat after bleomycin inhalation. Intensive Care Med 30: 489495, 2004.
14. Ashcroft T, Simpson JM, Timbrell V. Simple method of estimating severity of pulmonary fibrosis on a numerical scale. J Clin Pathol 41: 467-470, 1988.

15. Lindenschmidt RC, Tryka AF, Godfrey GA, et al. Intratracheal versus intravenous administration of bleomycin in mice: Acute effects. Toxicol Appl Pharmacol 85: 6977, 1986.

16. Chandler DB, Hyde DM, Giri SN. Morphometric estimates of infiltrative cellular changes during the development of bleomycin-induced pulmonary fibrosis in hamsters. Am J Pathol 112: 170-177, 1983.

17. Parvinen LM, Kilkku P, Mäkinen E, et al. Factors affecting the pulmonary toxicity of bleomycin. Acta Radiol Oncol 22: 417-421, 1983.

18. Nobukuni S, Watanabe $\mathrm{K}$, Inoue J, et al. Cigarette smoke inhibits the growth of lung fibroblasts from patients with pulmonary emphysema. Respirology 7 : 217-223, 2002.

19. Carnevali S, Nakamura $\mathrm{Y}$, Mio T, et al. Cigarette smoke extract inhibits fibroblast-mediated collagen gel contraction Am J Physiol 274: 591-598, 1998.

20. Iwai KT, Mori N, Yamada M, et al. Idiopathic pulmonary fibrosis: Epidemiologic approaches to occupational exposure. Am J Respir Crit Care Med 150: 670-675, 1994.

21. Hubbard R, Lewis S, Richards K, et al. Occupational exposure to metal or wood dust and aetiology of cryptogenic fibrosing alveolitis. Lancet 347: 284-289, 1996.

22. Baumgartner KB, Samet JM, Stidley CA, et al. Cigarette smoking: a risk factor for idiopathic pulmonary fibrosis. Am J Respir Crit Care Med 155: 242-248, 1997.

23. Lower EE, Strohofer S, Baughman RP. Bleomycin causes alveolar macrophages from cigarette smokers to release hydrogen peroxide. Am J Med Sci 295:193$197,1988$.

\section{Correspondence}

Dr. Emin MADEN

Selçuk Üniversitesi Meram Tıp Fakültesi

Göğüs Hastalıkları Anabilim Dalı

Meram, Konya / TURKEY

Tel: (+90.332) 2236874

e-mail: eminmaden@yahoo.com 